\title{
Job satisfaction and dissatisfaction among family health strategy professionals in a small city of Southern Brazil
}

\author{
Jacks Soratto ${ }^{(1)}$ \\ Silvana Cunha Fernandes ${ }^{(1)}$ \\ Cyntia Fontanella Martins ${ }^{(1)}$ \\ Cristiane Damiani Tomasi ${ }^{(1)}$ \\ Maria Teresa Brasil Zanini ${ }^{(1)}$ \\ Hosanna Pattrig Fertonani(1)
}

(1) Universidade do Extremo Sul Catarinense, Criciúma, Santa Catarina, Brasil.

Source of support: Conselho Nacional de Desenvolvimento Científico e Tecnológico (CNPq) and Universidade do Extremo Sul Catarinense (UNESC).

Conflict of interest: Nonexistent

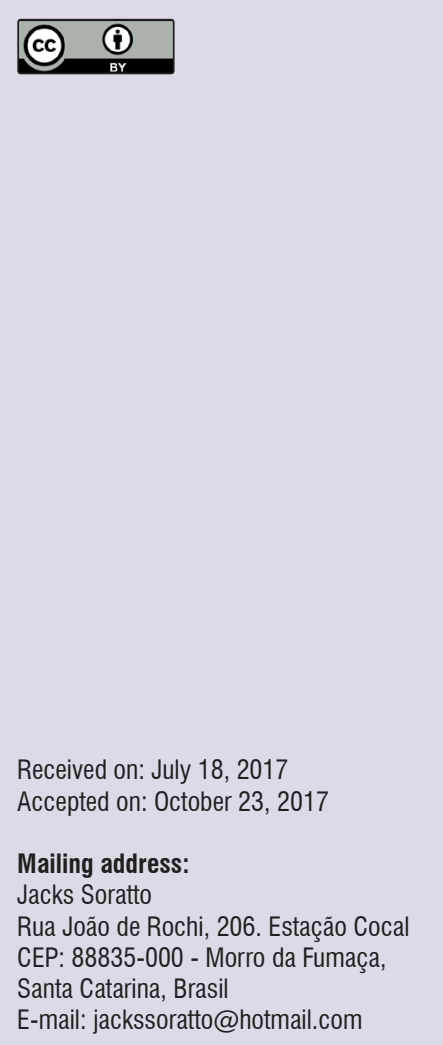

\section{ABSTRACT}

Objective: to identify aspects that generate satisfaction and dissatisfaction among Family Health Strategy professionals working in the city of Cocal do Sul, SC.

Methods: a qualitative study, conducted with 15 health professionals of three Family Health Strategy agencies. Data analysis was performed based on content analysis, supported by Atlas.ti software.

Results: the results were structured from two macro categories, composed of five subcategories, which added 194 excerpts from 23 codes. The aspects related to satisfaction of the Family Health Strategy professionals were grouped into three subcategories, namely: satisfaction in the identification with the staff and work; satisfaction based on relationships with patients; and, structural work conditions and satisfaction. Within health professional dissatisfaction, two subcategories were created: dissatisfaction related to aspects of health management and the relationship between staff and patients, as promoters of dissatisfaction.

Conclusion: the factors contributing to satisfaction and dissatisfaction are associated with working conditions and the work relationships established in professional practice.

Keywords: Primary Health Care; Unified Health System; Family Health Strategy; Job Satisfaction; Working Conditions 


\section{INTRODUCTION}

The present study embraced satisfaction and dissatisfaction among professionals who work in the Family Health Strategy (FHS), in a small city in the south of the state of Santa Catarina.

Primary Health Care (PHC) in Brazil is mainly represented by the FHS. The FHS is composed of a multiprofessional team committed to actions of health promotion, prevention, diagnosis of disease and health rehabilitation of the population attached to its territory. Currently, 40,162 Family Health teams (FHt) are integrated within Brazil 1,2.

The FHS professionals face different problems that cause dissatisfaction, such as difficulty with administration and management of people, lack of materials needed for work and to meet the population demands, which can cause increased workloads, considerable distress of health professionals, and compromise the results of the care provided ${ }^{3}$.

On the other hand, the work in the FHS establishes relationships with other professionals and increases the possibility of providing health care for more age ranges; and the workplace can be a space that promotes professional satisfaction.

In this way, satisfaction and dissatisfaction are in the locus of professionals' action of the FHS, and to understand their singularities is the challenge that drives us $^{4}$.

In view of the above, this study aims to identify aspects generating satisfaction and dissatisfaction in the work of FHS professionals in the city of Cocal do Sul, state of Santa Catarina, Brazil.

\section{METHODS}

The data collection met all the ethical precepts recommended for research with human beings, and it was conducted after receiving authorization of the responsible groups from the health units where this study was conducted and by the Ethics Committee of the Universidade do Extremo Sul Catarinense - UNESC, with opinion: 1,7858 CAAE: 60309416.2.0000.0119. This was a descriptive, exploratory, qualitative study, ${ }^{5}$ as outlined by the National Primary Health Care Policy (PNAB Política Nacional de Atenção Basica) ${ }^{1}$, utilizing theoretical reflections on the health work process ${ }^{6-8}$.

The present study was conducted in the city of Cocal do Sul, in southern Santa Catarina State, Brazil, in three FHS agencies, with one Family Health team (FHt) at each facility. The participants were 15 health professionals, namely: nurse [3], physician [2], nursing technician [4], dentist [3], and oral health technician [3]. The number of participants was considered sufficient using the criteria of data saturation, that is, when the researcher no longer recognizes new explanations, interpretations or descriptions of the phenomenon studied among the participants ${ }^{5,9}$.

The city of Cocal do Sul was selected because is close to the central region of Criciúma city, Santa Catarina; it has a Primary Health Care network that is regionally recognized; its managers has been previously worked in the municipal health secretary; and, finally, to understand the dynamics of a small city, since the studies on satisfaction and dissatisfaction are conducted in municipalities with a high population contingent and a very significant care network.

The criteria for choice of the $\mathrm{FHt}$ and participants were: FHt with a mean above and significantly above the mean in the last evaluation of the National Program for Improving Access and Quality of Primary Care (PMAQ-AB); FHt composed of all components established for a minimum team, as recommended by the $\mathrm{PNAB}^{1}$; and health professionals integrated into the $\mathrm{FHt}$ with higher education and technical education.

The data collection was performed by two techniques used in qualitative research: semi-structured interview and indirect observation. The interviews had a script composed of 15 questions; seven were closed-ended, to identify the profile of the participants and eight were open-ended with an emphasis on the research object of this study, which contemplated professional motivation aspects related to job satisfaction and dissatisfaction.

The interviews were conducted between March 22 and April 11, 2017, in a reserved room of the Health Units that participated in the study. All the interviews were recorded, totaling 109 minutes and 48 seconds; after recording, they were transcribed into a text-editing program.

In turn, indirect observation was used as a complementary technique, aiming to support the researcher in the interpretation of findings obtained during the interviews. This was performed during the FHS visit and the interview intervals, totaling 12 hours of observation.

The data were organized according to the precepts of content analysis, which is divided into three phases: pre-analysis, material exploration and interpretation ${ }^{10}$ and was supported by Atlas.ti qualitative data analysis software. In summary, the interviews were uploaded in the software, some parts were selected, and then codes were developed and grouped according to two 
groups [macro categories] previously defined, namely: professional satisfaction with the Family Health Strategy and professional dissatisfaction with the Family Health Strategy. The description of the phases of content analysis and the software followed the protocol proposed by Soratto ${ }^{11}$.

The participants' free participation and anonymity were guaranteed through the use of an alphanumeric code consisting of the letters $\mathrm{P}, \mathrm{C}$, which typifies the participant and the city of Cocal do Sul, respectively, and a number assigned to the sequence of the interviewee, for example: PC1, and so on, successively.

\section{RESULTS}

The results were structured from two macro categories, composed of five subcategories, which grouped 194 statements excerpted from 23 codes. It is important to note that sections of statements that were related to one or more codes were included. In order to generate a better understanding for the reader, combining theory and perception of researchers, we will highlight the statements excerpted in the discussion section.

The macro category, satisfaction of professionals, aggregated a total of 109 excerpts from participants' statements, associated to 12 codes, according to the following Table:

Table 1. Description of codes and number of statements excerpted related to health professional satisfaction in the city of Cocal-SC

\begin{tabular}{ccc}
\hline Codes & \multicolumn{2}{c}{ Statements excerpts } \\
\cline { 2 - 3 } & $\mathbf{n}$ & $\%$ \\
\hline Relationship with the team & 23 & 21 \\
Relationship with the patient & 16 & 15 \\
Work organization & 16 & 15 \\
Patient problem resolution & 11 & 10 \\
Health management & 9 & 8 \\
Materials needed for work & 9 & 8 \\
Physical structure & 6 & 6 \\
Patient follow up & 6 & 6 \\
Locality of the unit & 5 & 5 \\
Enjoying what one does & 4 & 4 \\
Working hours & 3 & 3 \\
Specialized service & 1 & 1 \\
\hline Total & 109 & 100 \\
\hline
\end{tabular}

The 12 codes described in Table 1 were grouped into three subcategories, namely: satisfaction with identifying with the staff and the work; satisfaction based on relationships with patients; and, structural work conditions and satisfaction. These relationships are described in the following Figure: 


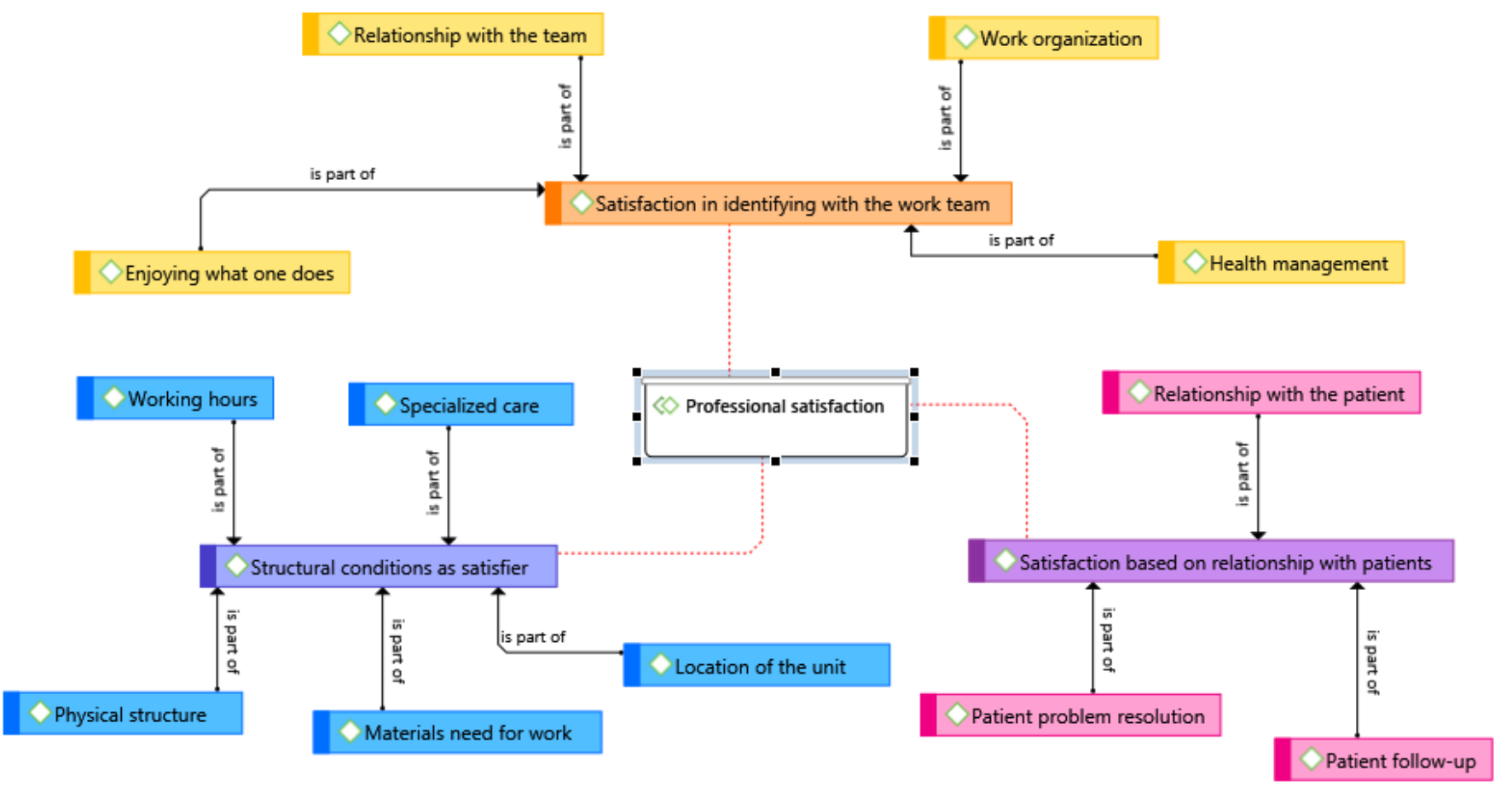

Figure 1. Relationship between macro categories, subcategories and satisfaction codes of Family Health Strategy professionals in the city of Cocal do Sul, SC, Brazil

The macro category, professional dissatisparticipants associated to 11 codes. Table 2 shows the faction, aggregated 85 statements excerpts from the number of statements excerpted related to the codes.

Table 2. Description of the codes and number of statements excerpted related to health professional dissatisfaction in the city of Cocal, SC, Brazil

\begin{tabular}{ccc}
\hline Codes & \multicolumn{2}{c}{ Statements excerpted } \\
\cline { 2 - 3 } Salary & $\mathbf{n}$ & $\%$ \\
\hline Lack of professionals & 22 & $26 \%$ \\
Patient complaints & 18 & $21 \%$ \\
Absence of a career plan & 11 & $13 \%$ \\
Overwork & 10 & $12 \%$ \\
Need for structural improvements & 6 & $7 \%$ \\
Workload & 4 & $5 \%$ \\
Lack of patient co-responsibility & 3 & $4 \%$ \\
Time for lunch & 3 & $4 \%$ \\
Relationship with the team & 3 & $4 \%$ \\
Lack of patient comprehension & 3 & $4 \%$ \\
\hline Total & 2 & $2 \%$ \\
\hline
\end{tabular}


The 11 codes described in Table 2 were grouped into two subcategories, namely: dissatisfaction related to aspects of health management; the relationship between the team and the patient as a promoter of dissatisfaction. These relationships are described in the following figure:

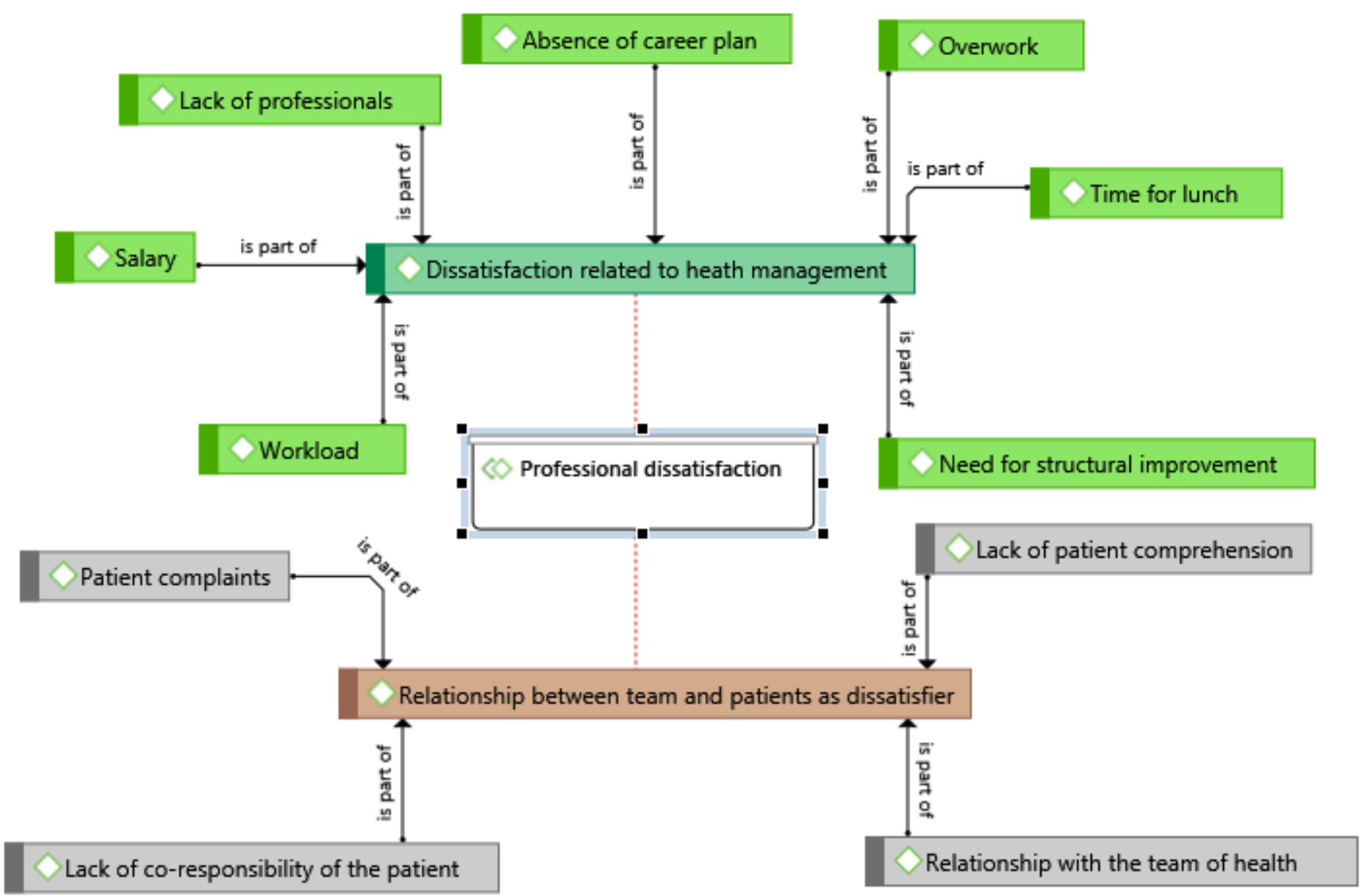

Figure 2. Relationship between macro categories, subcategories and codes of dissatisfaction of the Family Health Strategy professionals in the city of Cocal do Sul, SC, Brazil

\section{DISCUSSION}

\section{Satisfaction of family health strategy professionals and Satisfaction with identifying with the staff and the work}

The activities developed in the FHS presuppose the exercise of care and management practices, democratic and participative, in a form of a teamwork, driven to populations of defined territories, for which the sanitary responsibility is embraced, considering the dynamics existing in the territory in which these populations are living ${ }^{1}$.

The relationships established in the team are essential for union and exchange of knowledge. Respect among professionals is also essential for better team organization. In the city in question, the data show that satisfaction is related to the ability of establishing a good relationship, according to the following statements:

"It's very good, it's my second family, the family we live in, much more here than at home. It is very good, sometimes, of course, as each one has his opinion, sometimes the opinions are not the same, but we talk, determine the best possible manner to care for the patient. In everyday life we get along, we have fun with each other; at the end of the year we do the secret friend exchange"(PC10).

"The professionals are well trained, the nurse has a lot of experience, she coordinates the team; I have worked on several other FHS teams that were very complicated" (PC7). 
The unity of the team is a fundamental aspect for working well within the FHS. The coordination and management aspect were also taken into account, as it is a management prerogative to listen to the demands of patients and professionals.

The manager that collaborates with the professional, in regard to the abilities of listening and dialogue, collaborates to improve the team's work processes and, consequently, generates satisfaction. Teamwork can be a resource for promoting satisfaction, strengthening relationships, creating a network of support and co-responsibility for the work that is not only accomplished by the professional, but by an entire team.

In the FHS, the team establishes a practice in which communication among professionals should be part of the daily exercise of work: joining of technical interventions by means of mutual responsibility ${ }^{12}$.

The organization of the work involves the way they are divided, the roles played in the production process, and the type of management control and practices ${ }^{6,7}$. Even though there are divisions of work in each $\mathrm{FHt}$, there is unity among its members. Participants demonstrate satisfaction with elements that are associated with the health care model that targets PHC, especially the FHS.

The enjoyment of what one does was another aspect strongly emphasized by professionals as a satisfier. This item was directly related to identification by the profession; even when faced by negative aspects, it motivates the professional, as follows:

"I'm very happy with my profession, I could not do anything else. You have to work doing what you like, because if you do not like it you can not take it, then you will be stressed all the time, your service will not flow, and the patients will not talk with you. Appreciating what you do is important for satisfaction" (PC4).

The statement seems simple, but it has a considerable effect when we think that many professionals see the job as something boring. Working is a source of satisfaction and creativity, when it meets the needs in a process in which the object and human being are transformed, and the worker see himself in the work being done; in other words, "what the Greeks called poiesis, which means my work, what I do, what I build, where I see myself, my creation, in which I create myself in the measure that I create in the world " ${ }^{13}$.

When the professional is dissociated from the work he performs, he becomes part of an arrangement without interference. The consequence of this process is professional alienation and, consequently, generation of dissatisfaction, as the product of what he does is not recognized?.

\section{Satisfaction based on relationships with patients}

The work in the FHS, and the profession, can be a resource of help to the patients, who often do not have a correct orientation on the ways of the health system; this is something understood as a satisfactory aspect. The following statements demonstrate these results:

One thing that gives a lot of satisfaction is when a patient who has a lot of problems, like a child, and you take care of her, you develop a friendship in school, and then they come, and let you care for their teeth without crying, because you already created that friendship, they enter into the office hand-in-hand with us [...] then this bond is very cool "(PC10).

"I think working in health is good. It is good because people can be helped by me, and my gratification is different; it is when you see a wound of five years closing; it is when you see a person having good glycemic control, a person with a stroke being able to recover and coming to the unit, so this is very gratifying" (PC5).

What is evident in the statements is that satisfaction is strictly linked to one of the attributes of PHC, namely, the longitudinality. The bond between the patient and the professional is important for achieving this attribute, and for that professional to commit to the broad aspects related to the patient life.

The longitudinality of care presupposes the continuity of the clinical relationship, with development of a bond and accountability between professionals and patients over time, and permanently ${ }^{1,14}$. The longitudinality exercise also aims to diagnose and plan more precise treatments, which reduces the number of referrals to specialists, and unnecessary procedures.

The health professionals' formation, when unrelated to the study of the relationship between the reality of living conditions and population health, results in a lack of preparation to deal with the complexities of human life, which constitutes an obstacle to achieving longitudinality in the FHS.

Professional satisfaction is related to the fact that they can strengthen a relationship with the patient. This link between professional and patient is materialized by 
means of manifestation of the professional's interest in the community in which he is integrated, through acts of trust and respect.

Follow-up and the professional-patient bond are things that unify people, indicate interdependence and relationships with two-way communication, commitments of professionals with patients and vice-versa; consequently, these provide satisfaction ${ }^{15}$.

\section{Structural work conditions and satisfaction}

The place where the FHS activities is performed is seen as a potential promoter of satisfaction. Working in an agency maintaining minimal levels of structural conditions, such as ventilation and lighting, which provides a welcoming environment, is a commitment of health managers. The following statements show that the working conditions of professionals have contributed to increased levels of satisfaction:

"[...] is the part of the ambulatory clinic that is well structured; we have everything, physical structure, air conditioning, so, there is quality in the environment itself, it was good, at first" (PC3).

"It's hard to be absent from work; Cocal do Sul is almost perfect, medication is barely out of stock, It's very difficult not to have a dressing." (PC2).

According to reports from the interviewees, the health units are well structured, both in structure and materials for daily work, and this benefits the good practice of quality care and professional satisfaction. This result collaborates some studies ${ }^{3,11}$ that support the physical structure, and absence of supplies, as something that contributes to dissatisfaction of the health professionals who work in the FHS.

This opposite result that demonstrates a solid structural network in the city can be justified by a management of continuity, which were committed even with political changes, with the promotion of minimum guarantees for health work in $\mathrm{PHC}$, especially in the FHS.

\section{Dissatisfaction of family health strategy professionals and Dissatisfaction related to aspects of health management}

It is important to note that, even when the data show that, the physical structure is of good quality in the city, and when it is a satisfactory element, the participants maintain the need for structural improvements, such as repairs, renovations, and paintings, as dissatisfier.
The places where health actions are developed should be constantly assisted by managers, to reduce factors that contribute to professional demotivation and, consequently, worsen the quality of care.

The absence of a plan of positions and salaries, potential for promotion within the institution, and consequently a better salary, were reasons that contributed to dissatisfaction, according to the following statements:

"We do not have a career plan, we have nothing that increases our salary [...] you plan, try to do the best work, and the issue of financial recognition does not exist. Cocal used to have one of the best nursing salaries, and nowadays it is one of the most outdated "(P10).

"I'll be honest, the salary could be better, because as I told you, there is a lot of service overload due to population demand, and we are also dealing with people, so we deserve it" (P8).

Salary is not a motivating factor among the interviewees, because other aspects, such as workload, overwork and career plan are also taken into account, because of all responsibility that the health team has within the society.

The culture of adopting a position and salary plan in the health area, especially in the FHS, is still small. Only $21 \%$ of Brazilian professionals have it established ${ }^{16}$.

It is evident that a great need for investments by the management staff exists, and strategies for salary improvement, since this can influence the performance of this professional, the quality of life inside and outside the FHS, and the retention within or abandonment of the profession.

The lack of professionals inside and outside the units was another aspect mentioned by the participants; they have difficulty referring patients, for specialized demands and even for urgent and emergency care. This is true of the Family Health Support Center (NASF - Núcleo de Apoio à Saúde da Família), which is a crucial tool to complement actions in the FHS, and has not yet implanted in the city.

"Scheduling actions is also part of the management of the FHS, planning actions without having the right professionals to work with this; Cocal do Sul has no NASF, - so it is difficult to plan actions, they try to do such a job, which generates certain dissatisfaction in us" (PC2).

"Physicians are not available, sometimes; we could have more physicians, more employees, because 
there is lack of medical care, patients come for them, but there are no physicians [...]" (PC11).

The lack of professionals is reflected not only the routines of staff who need to work excessively to meet the demand, but also in the lives of patients; when they need some form of treatment, it is not available, or it is delayed.

In terms of overtime of some professionals, who complain of an excess of work, the majority of the professionals work 40 hours weekly [11]; others [4] have double journey due to another job, because of the daily routines.

"The working hours could be fewer; our lunch time, a longer interval, we leave at noon and at one o'clock we have to come back, documenting this on the timecard. The service takes a lot of time out of our lives "(PC9).

Excessive working hours can cause physical exhaustion, as well as social loss for the professional ${ }^{3,17}$, considering the reduced time he has for family life.

Overwork can have major consequences for the health professional and can contribute to a greater likelihood of negligence in certain activities, jeopardizing the quality of care provided. As a result, the professional can compromise the quality of care provided, causing harm to the person receiving care, as follows:

"A lot of demand, and the problem I see here now is that sometimes, as right now, there is not a permanent physician; we explain it and the patients do not understand, they think it's our fault. I feel this is difficult, it ends up overloading, and many people, they are a little more demanding. And one of the problems we are facing is the elderly, they are increasing a lot, we provide 20 places each week, but if 20 more appointments were available, it would not be enough, so we hear a lot of complaints, which makes us unmotivated and dissatisfied with the service" ( PC8).

"Among several dissatisfactions, the main one is not being able to meet the demand" (PC5).

The excess demand, because of an overestimated territory, or the local culture of the Health Unit, weakens one of the activities foreseen in the FHS, which is welcoming people for spontaneous needs, in order to favor access for the attached population. Welcoming involves actions that must be performed in all health care points, among them primary care services, especially in the FHS ${ }^{9}$. Having excessive demand impairs this welcoming, so the professional cannot provide quality care, resulting in dissatisfaction.

The results still show that bureaucratic aspects of the FHS function cause dissatisfaction. In the units, the working time is not only for care, but also for administrative activities, such as documenting in records, and completing reports.

\section{The relationship between the team and the patient as a dissatisfier}

Working in the FHS implies knowing how to interact with different people ${ }^{6}$. The conviviality with these differences is not always congruent, since some FHS patients disrespect the professionals, they are not willing to adhere to the treatment offered, nor cooperate for a good relationship between them, causing professional dissatisfaction. The following statement sums up this situation:

"But it is very stressful because, nowadays, the patient is still like that, he comes and drops a problem for the health professional, as if the problem were not his, and in fact he has co-responsibility with the situation, with his treatment. You give all the directions, and at home he does everything wrong; he does not take responsibility, so this generates some stress for the health professional; actually, I feel some pressure, but sometimes the patient does not want the responsibility. They are still not taking over; it is difficult to convince a person to follow the treatment, correctly" (PC13).

It is also common that problems occur in the relationships between professionals and patients, but it is up to the professional to develop abilities for coexistence and management of these conflicts. The attitudes of colleagues who share work in the FHS also generate dissatisfaction. It was possible to verify that the participants present difficulties in the relationship between the team members:

"There are people in here who to pull the rug from under the feet of each other; but this is everywhere, the salary is low" (PC14).

"I think that the more difficult thing is to deal with the team, it is very complicated, not saying that the team is complicated, it is that I care a lot about living together, good living together, then, to draw attention of a professional, a co-worker, about your work, is very complicated "(PC2). 
The relationship between the team is a point that must be discussed among the professionals of the units and managers. Many of these professionals show difficulties with resolving conflicts between colleagues and managers. It is necessary to review actions within the FHS; perhaps actions of continuing education in health can reduce these conflicts and minimize the element that promotes dissatisfaction.

\section{CONCLUSION}

The factors that contribute to satisfaction and dissatisfaction are associated with working conditions and relationships that are established in the exercise of these activities. The analysis of the reasons that lead to the satisfaction and dissatisfaction with the work in the FHS revealed routine situations of the working process in health involving professionals, managers, and users of the FHS.

The study emphasizes the need for investments in human capital, care and valuing of the professional, by means of implementing career and salary plans, professional qualification, strengthening multidisciplinary work from an interdisciplinary perspective, and intersectoral work, with a view to care, minimizing the problems in the care network.

Finally, based on the analysis of the factors of satisfaction and dissatisfaction, the present study may be useful for changes and improvements in the micro spaces of PHC, especially in the FHS. Additionally, there is the opportunity for the development of coping strategies, especially for training future professionals who will work in the FHS, with the aim of better preparing these professionals in light of the possible factors of dissatisfaction uncovered.

\section{ACKNOWLEDGEMENTS}

The Municipal Secretary of Health of Cocal do Sul, SC, Brazil, the study participants, CNPq and UNESC for granting a scholarship by the Institutional Program of Scientific Initiation Scholarships (PIBIC).

\section{REFERENCES}

1. Brasil. Ministério da Saúde. Secretaria de Atenção à Saúde. Departamento de Atenção Básica. Política Nacional de Atenção Básica (PNAB). Brasília: Ministério da Saúde; 2012 [acesso em: 2017 Jun 3]. Disponível em: http://dab.saude.gov.br/ portaldab/pnab.php.
2. Brasil. Ministério da Saúde. Departamento da Atenção Básica. Histórico de Cobertura da Atenção Básica e Saúde da Família. Brasília: Ministério da Saúde; 2017 [acesso em: 2017 Jul 9]. Disponível em: http://dab.saude.gov.br/dab/historico cobertura_sf/historico_cobertura_sf_relatorio.php.

3. Trindade LL, Pires DEP. Implicações dos modelos assistenciais da atenção básica nas cargas de trabalho dos profissionais de saúde Texto Contexto Enferm. [periódico na internet]. 2013 [acesso em 2017 jul. 1] 22(1):36-42. Disponível em: http://www. scielo.br/pdf/tce/v22n1/pt_05.pdf.

4. Lima L, Pires DEP, Forte ECN, Medeiros F. Job satisfaction and dissatisfaction of primary health care professionals. Esc Anna Nery [periódico na Internet]. 2014 [acesso em 2017 jul. 1]; 18(1):[17-24]. Disponível em: http:// dx.doi. org/10.5935/1414-8145.20140003.

5. Morse JM. Critical analysis of strategies for determining rigor in qualitative inquiry. Qual Health Res [periódico na Internet]. 2015 [acesso em: 2017 Jun 12]; 25:[1212-22]. Disponivel em: http://dx.doi. org/10.1177/1049732315588501.

6. Dejours C. Psicodinâmica do trabalho e teoria da sedução. Tradução de Gustavo A. Ramos Mello Neto. Psicol Estud [periódico na Internet]. 2012 [acesso em: 2017 Jun 10]; 17:[363-71]. Disponível em: http://www.redalyc.org/articulo. oa?id=287126284002.

7. Souza DO, Mendonça HF. Trabalho, ser social e cuidado em saúde: abordagem a partir de Marx e Lukács. Interface (Botucatu) [periódico na Internet]. 2017 [acesso em: 2017 Jul 18]; 21(62):543-52. Disponível em: http://dx.doi. org/10.1590/1807-57622016.0482.

8. Pires DEP, Trindade LL, Matos E, Azambuja EP, Borges AMF, Forte ECN. Inovações tecnológicas no setor saúde e aumento das cargas de trabalho. Rev Tempus Actas Saúde Colet. 2012 [acesso em: 2017 Jun 28]; 6:45-59. Disponível em: http://dx.doi. org/10.18569/tempus.v6i2.1113.

9. Minayo MCS. Amostragem e saturação em pesquisa qualitativa: consensos e controvérsias [Internet]. Rev Pesquisa Qualit. [periódico na Internet]. 2017 [acesso em: 2017 Jun 18]; 5(7):1-12. Disponível em: http://rpq.revista.sepq.org.br/index. $\mathrm{php} / \mathrm{rpq} /$ article/view/82.

10. Bardin L. Análise de conteúdo. Tradução Luís Antero Reto e Augusto Pinheiro. São Paulo (SP): Edições 70; 2011. 
11. Soratto J. Satisfação e insatisfação no trabalho de profissionais da Estratégia Saúde da Família [tese]. Florianópolis (SC): Universidade Federal de Santa Catarina; 2016.

12. Backes DS, Backes MTS, Erdmann AL, Büscher A, Marchiori MT, Koerich MS. Significado da atuação da equipe da Estratégia de Saúde da Família em uma comunidade socialmente vulnerável. Ciênc. saúde coletiva [periódico na Internet]. 2012 [acesso em: 2017 Jul 18]; 17(5): [115157]. Disponível em: http://dx.doi.org/10.1590/ S1413-81232012000500009.

13. Cortella MS. Qual é a tua obra?: inquietações propositivas sobre gestão liderança e ética. 19. ed. Petrópolis: Vozes, 2012.

14. Oliveira MAC, Pereira IC. Atributos essenciais da atenção primária e a estratégia saúde da família. Rev Bras Enferm [periódico na Internet]. 2013 [acesso em: 2017 Jun 18];66(esp):158-64. Disponível em: http://dx.doi.org/10.1590/ S0034-71672013000700020.

15. Campos GWS, Figueiredo MD, Pereira-Júnior N, Castro CP. A aplicação da metodologia Paideia no apoio institucional, no apoio matricial e na clínica ampliada. Interface (Botucatu) [periódico na Internet]. 2014 [acesso em: 2017 Jun 18];18(Suppl1):983-95. Disponível em: http:// dx.doi.org/10.1590/1807-57622013.0324.

16. Seidl H, Vieira SP, Fausto MCR, Lima RCD, Gagno J. Gestão do trabalho na atenção básica em saúde: uma análise a partir da perspectiva das equipes participantes do PMAQ-AB. Saúde Debate [periódico na Internet]. 2014 [acesso em: 2017 Jun 28]; 38(especial):94-108. Disponível em: http:// dx.doi.org/10.5935/0103-1104.2014S008.

17. Pires DEP, Trindade LL, Matos EM, Azambuja $E P$, Borges AMF, Forte ECN et al. Inovações tecnológicas no setor saúde e aumento das cargas de trabalho. Rev. Tempus Actas de Saúde Coletiva [periódico na Internet]. 2012 [acesso em: 2017 Jun 11] 6(2):45-59. Disponível em: http://dx.doi. org/10.18569/tempus.v6i2.1113. 